\title{
Sea surface temperature changes in the Southern California Borderlands during the last glacial-interglacial cycle
}

\author{
P. Graham Mortyn, 1,2 Robert C. Thunell, ${ }^{1}$ David M. Anderson, 3 \\ Lowell D. Stott, ${ }^{4}$ and Jianning Le 1
}

\begin{abstract}
A variety of evidence suggests that average sea surface temperatures (SSTs) during the last glacial maximum in the California Borderlands region were significantly colder than during the Holocene. Planktonic foraminiferal $\delta^{18} \mathrm{O}$ evidence and average SST estimates derived by the modern analog technique indicate that temperatures were $6^{\circ}-10^{\circ} \mathrm{C}$ cooler during the last glacial relative to the present. The glacial plankton assemblage is dominated by the planktonic foraminifer Neogloboquadrina pachyderma (sinistral coiling) and the coccolith Coccolithus pelagicus, both of which are currently restricted to subpolar regions of the North Pacific. The glacial-interglacial average SST change determined in this study is considerably larger than the $2^{\circ} \mathrm{C}$ change estimated by Climate: Long-Range Investigation, Mapping, and Prediction (CLIMAP) [1981]. We propose that a strengthened California Current flow was associated with the advance of subpolar surface waters into the Borderlands region during the last glacial.
\end{abstract}

\section{Introduction}

Attempts to reconstruct average glacial-interglacial sea surface temperature (SST) changes in the Southern California Borderlands were first made by Gorsline and Barnes [1972] using the oxygen-isotopic composition of planktonic foraminifera. These authors estimated that average SSTs warmed by approximately $6^{\circ} \mathrm{C}$ from the last glacial maximum (LGM) to the Holocene. Since this early work, a number of important developments have been made related to hindcasting SST [Imbrie and Kipp, 1971; Fairbanks and Matthews, 1978; Fairbanks, 1989]. It is important to be able to obtain reliable estimates of past temperature since SST is a critical boundary condition used in modeling of both past and future climates. In this study, we utilize both micropaleontologic and stable isotopic approaches to estimate average SST changes from the LGM to the present in the Borderlands region.

The Southern California Borderlands are an important region for paleoceanographic study because they lie within the eddy system of the California Current [Hickey, 1991], the eastern boundary current of the North Pacific gyre. In eastern boundary upwelling regions such as the California Current system, the flux of new nutrients into the euphotic zone, primary production, and the downward flux of particulate carbon are all enhanced relative to the open ocean [U.S. Global Ocean Ecosystems Dynamics (GLOBEC), 1992]. In the open ocean, very little of the organic carbon reaching the seafloor is preserved in sediments [Jahnke et al., 1982; Martin et al., 1991; Martin and Sayles, 1992], whereas

\footnotetext{
1 Department of Geological Sciences, University of South Carolina, Columbia.

2 Now at Scripps Institution of Oceanography, La Jolla, California.

3 NOAA Paleoclimatology Program, Boulder, Colorado.

4 Department of Earth Sciences, University of Southern California, Los Angeles.
}

Copyright 1996 by the American Geophysical Union.

Paper number 96PA01236.

0883-8305/96/96PA-01236\$12.00 over $60 \%$ of the organic carbon arriving at the seafloor in the Southern California Borderland Basins is preserved [Berelson et al., 1987]. If this difference is due to carbon flux variation, then eastern boundary current systems such as the California Current may play a major role in global geochemical cycles, and thus it is important to study past oceanographic conditions in these regions.

\section{Background}

Despite attempts to reconstruct the SST history of the California Borderlands region from the LGM to the present [Gorsline and Barnes, 1972; Kahn et al., 1981], the late Pleistocene record remains poorly documented. Gorsline and Barnes [1972] examined downcore planktonic foraminiferal $\delta^{18} \mathrm{O}$ variations from a range of species and coiling ratio changes of the planktonic foraminifer Neogloboquadrina pachyderma, and concluded that average glacial SSTs were approximately $8^{\circ} \mathrm{C}$ in the Borderlands and warmed to approximately $14^{\circ} \mathrm{C}$ during the Holocene.

Kahn et al. [1981] carried out a stable isotopic study of benthic and planktonic foraminifera from a late Pleistocene piston core from Tanner Basin. Their benthic foraminiferal results show that the $\delta^{18} \mathrm{O}$ of deep waters in this basin changed by $1.5 \%$ from the last glacial to the present, which they considered to be the "glacial effect." In addition, these authors estimated a "water-mass effect" on the glacial-interglacial $\delta^{18} \mathrm{O}$ change in planktonic foraminifera. Surface water paleotemperatures were then determined by subtracting the glacial and water-mass effects from the planktonic foraminiferal $\delta^{18} \mathrm{O}$ record. Using this approach, Kahn et al. [1981] estimated that glacial SSTs in this region were approximately $5^{\circ} \mathrm{C}$ cooler than at present.

The Cooperative Holocene Mapping Project (COHMAP), [1988] assembled a global array of well-dated paleoclimatic data and used general circulation models to identify and evaluate causes and mechanisms of climatic change during the last 18,000 years. Of relevance to our study is the COHMAP [1988] model simulation of climate conditions over the North Pacific for the LGM. According to this study, glacial climate conditions for this region were strongly affected by the presence of the Laurentide 
ice sheet over much of the North American continent. The ice sheet may have caused an anticyclone associated with a weakening and southerly migration of the North Pacific highpressure cell. A shift in the position of this pressure cell would have caused changes in the flow strength of the California Current.

\section{Oceanographic Setting}

The Southern California Borderlands are a series of basins that underlie the highly productive waters of the California Current and its associated eddies (Figure 1). The strength of the California Current changes in response to seasonal variations in the winds. Upwelling along the west coast of North America is forced by atmospheric circulation around the North Pacific highpressure cell that seasonally varies in both strength and position [Huyer, 1983]. The strength of the pressure gradient between the North Pacific high and the continental thermal low is the driving force for the surface winds in this area. The gradient is strongest during the summer when the low deepens (due to heating) and the North Pacific high increases in intensity [Reid et al., 1958]. Strong northerly winds during the spring and summer strengthen the current flow, with offshore Ekman transport causing coastal upwelling and high productivity [Huyer, 1983; Eppley, 1986]. Offshore Ekman transport is lower in the Borderlands than along the regions immediately to the north and south [Huyer, 1983] due to the offshore position of the California Current and the unfavorable orientation of the coastline relative to the prevailing winds. However, significant upwelling does occur in the Borderlands due to local wind stress curl [Thunell and Sautter, 1992]. In the winter, the northerly component of the wind weakens and a surface countercurrent (the Davidson Current) flows northward, landward of the California Current. These warm surface waters from the south result in reduced surface productivity [Tont, 1976].

\section{Methods}

\section{Sample Material}

Piston cores from Tanner, San Nicolas, Velero, and No Name Basins were used in this study (Figure 2). Table 1 provides a summary of core information including latitude, longitude, water depth, and core length. Each core was sampled at 5- to $10-\mathrm{cm}$ intervals for this study. Samples were disaggregated in a $100^{\circ} \mathrm{C}$ Calgon solution and wet sieved through a $63-\mu \mathrm{m}$ screen. Following drying, the sediment samples were sieved at $150 \mu \mathrm{m}$ and split into two separate aliquots for faunal and stable-isotope analyses.

\section{Stratigraphy and Chronology}

Oxygen-isotope analyses were performed on the planktonic foraminiferal species, Globigerina bulloides (150- to $250-\mu \mathrm{m}$ size fraction; Table 2). This species was chosen for two reasons. First, it was found to be sufficiently abundant at most sample depths and thus provides a continuous record. Second, this species primarily lives above the thermocline in this region [Sautter and Thunell, 1991] and thus records mixed-layer temperatures. Stable-isotope analyses were carried out at both the University of South Carolina (Velero and No Name Basin cores; lab precision $+/-0.2 \% o \delta^{18} \mathrm{O}$ ) and University of Southern Califomia (Tanner and San Nicolas Basin cores; lab precision $+/$ -

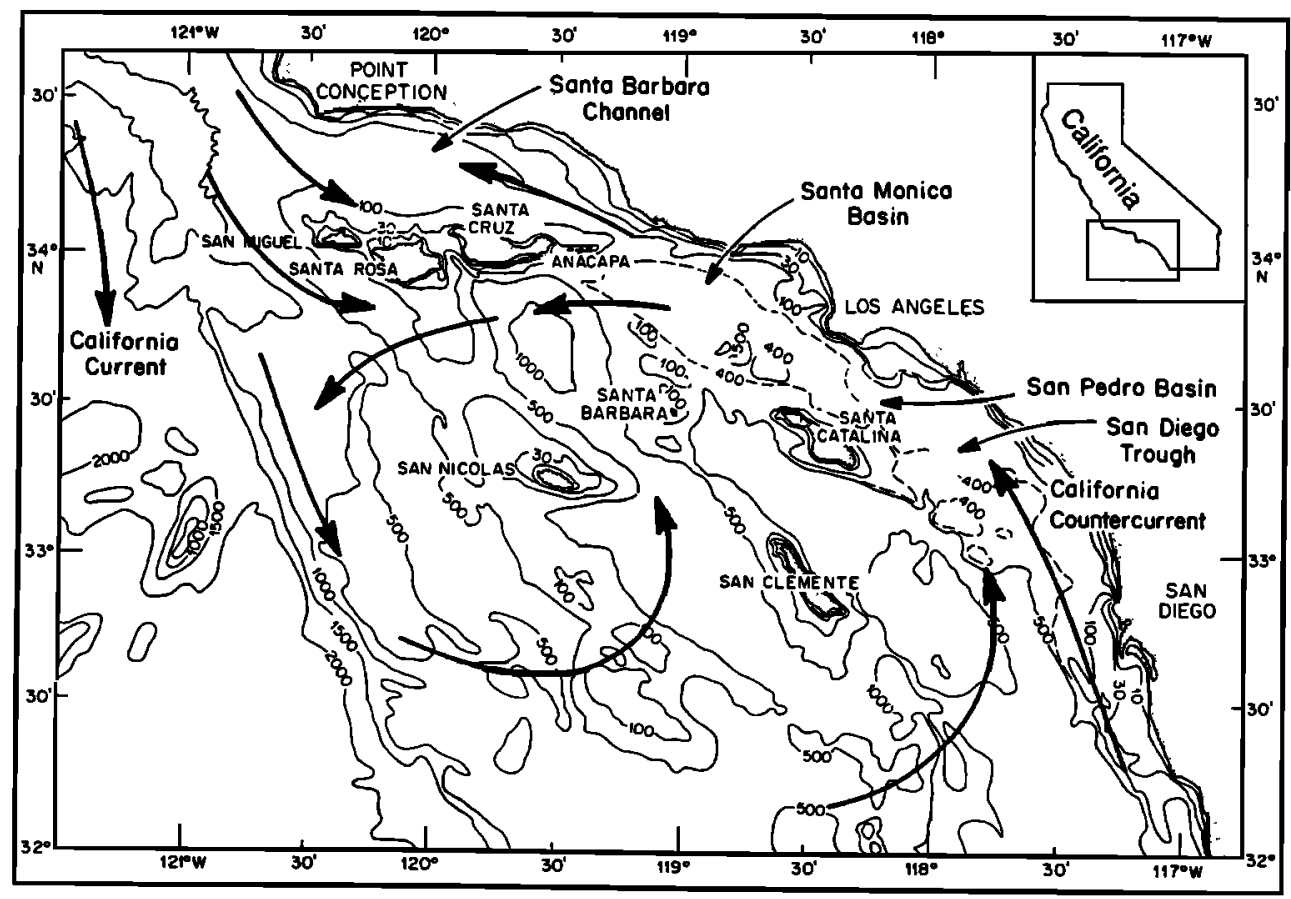

Figure 1. Mean surface circulation pattern in the Southern California Borderlands. Note that the California Current tums southeastward and then shoreward and poleward in a large eddy known as the the Southern California Countercurrent or the Southern California Eddy. Depth contours are in fathoms. Reprinted from Hickey [1992] with kind permission from Elsevier Science Ltd., The Boulevard, Langford Lane, Kidlington OX5 1GB, United Kingdom. 


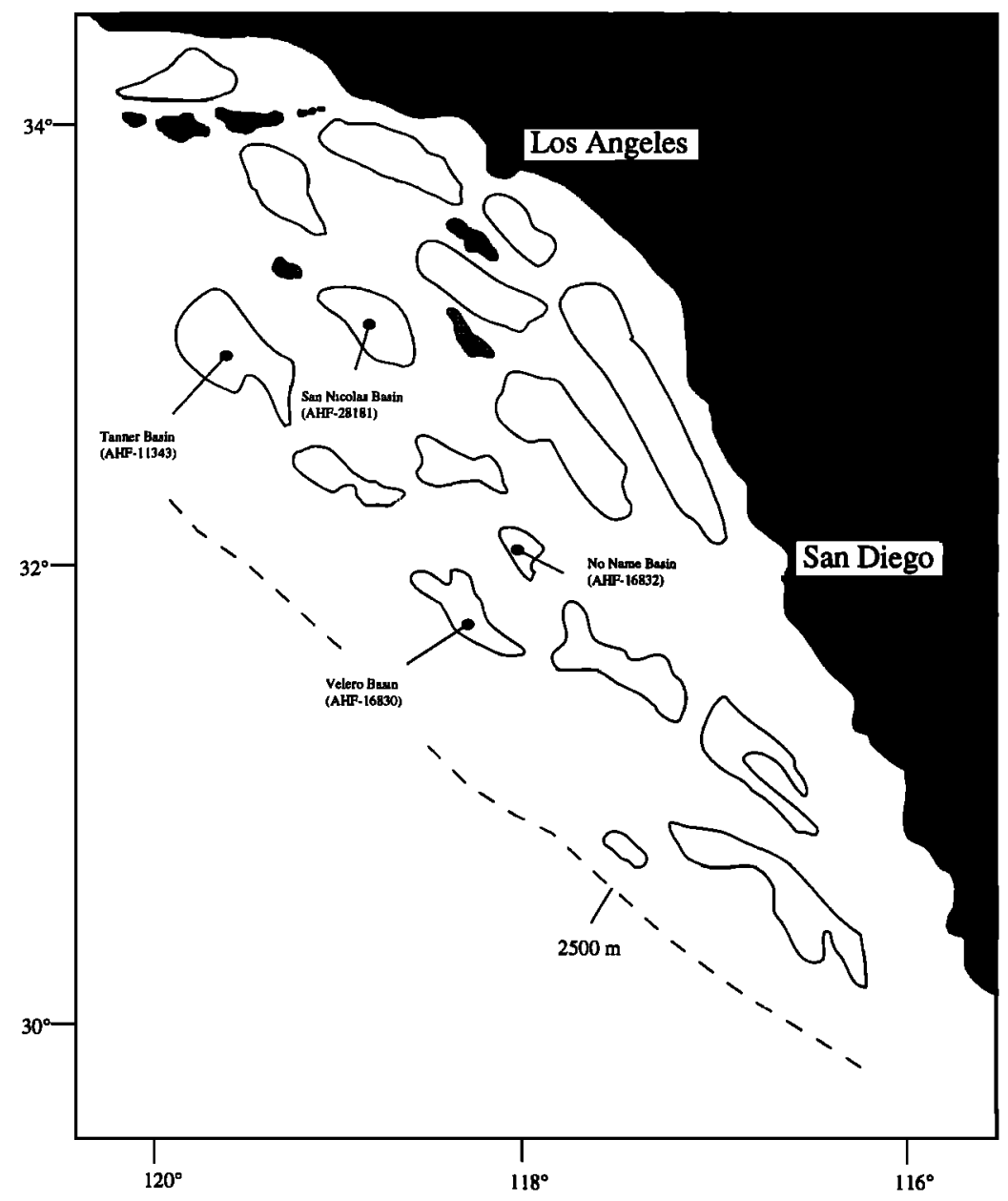

Figure 2. Map of Southern California Borderland basins. The locations of the four cores used in this study are indicated.

$0.2 \% \delta^{18} \mathrm{O}$ ) mass spectrometer facilities. All $\delta^{18} \mathrm{O}$ data are reported relative to the Pee Dee belemnite (PDB) standard in $\delta$ notation [Epstein et al., 1953].

The depths of the oxygen-isotope stage 1-2 and stage 2-3 boundaries are indicated for each core (Figure 3). These boundaries were estimated by taking the midpoint between light and heavy extremes in isotopic values. The stage 1-2 and 2-3 boundaries have been dated at approximately 12 and $24 \mathrm{ka}$, respectively [Imbrie et al., 1984; Martinson et al., 1987]. The $\delta^{18} \mathrm{O}$ profiles were used to establish a basic glacial-interglacial stratigraphy for each core.
Carbon $14\left({ }^{14} \mathrm{C}\right)$ dating of foraminiferal shells by accelerator mass spectrometry (AMS) was used to establish a chronology for each core. Mixed planktonic foraminiferal species were picked from several depths in each core and analyzed at the AMS ${ }^{14} \mathrm{C}$ dating facility at the University of Arizona (Table 3). Dating foraminiferal calcite samples (versus bulk sediment) eliminates the risk of contamination by older detrital carbonates [Bard, 1988], a problem encountered in the earlier studies of the Borderlands region [Gorsline and Barmes, 1972].

AMS ${ }^{14} \mathrm{C}$ dates obtained from foraminiferal samples must be corrected for the difference in ${ }^{14} \mathrm{C}$ composition between the

Table 1. Cores Used in This Study

\begin{tabular}{lccccc}
\hline Core & Location & North Latitude & West Longitude & Water Depth, m & Core Length, cm \\
\hline AHF-11343 & Tanner Basin & $32^{\circ} 48.0^{\prime}$ & $119^{\circ} 51.4^{\prime}$ & 1171 & 768 \\
AHF-28181 & San Nicolas Basin & $33^{\circ} 00.7^{\prime}$ & $119^{\circ} 03.6^{\prime}$ & 1756 & 296 \\
AHF-16830 & Velero Basin & $31^{\circ} 28.1^{\prime}$ & $118^{\circ} 25.0^{\prime}$ & 2451 & 409 \\
AHF-16832 & No Name Basin & $31^{\circ} 52.0^{\prime}$ & $118^{\circ} 07.0^{\prime}$ & 1829 & 564 \\
& & & & & \\
\hline
\end{tabular}



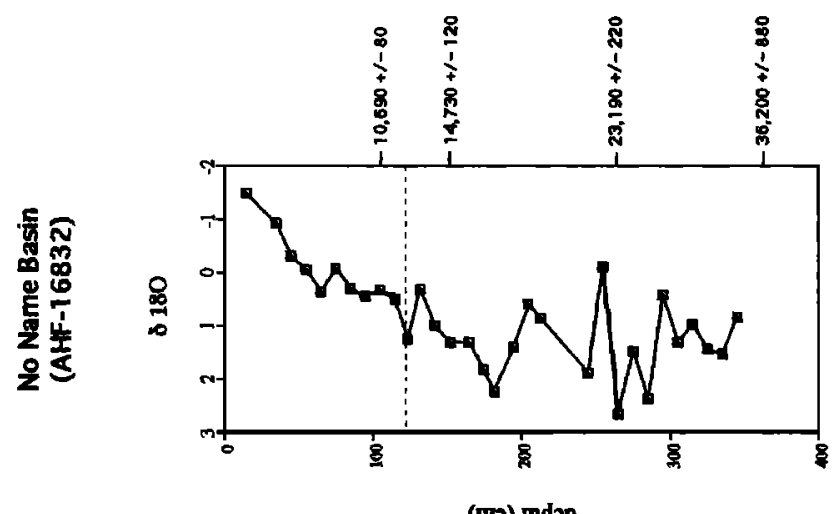

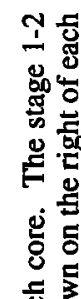

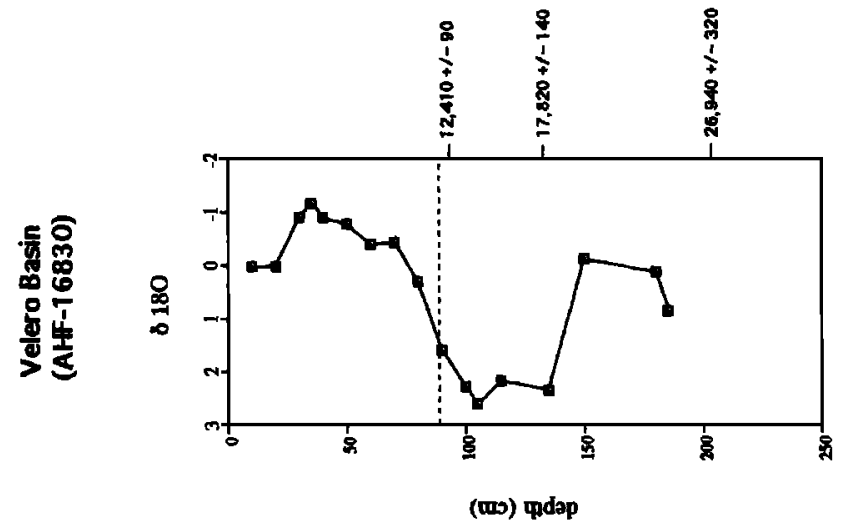

논

흥 웜

ธิ

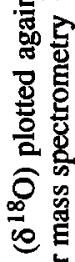

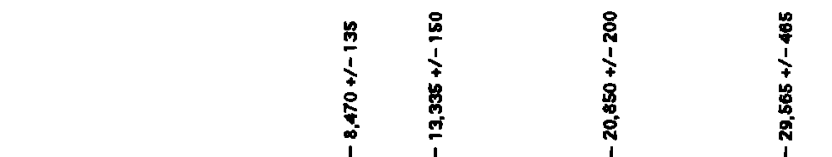

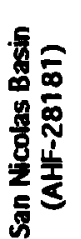
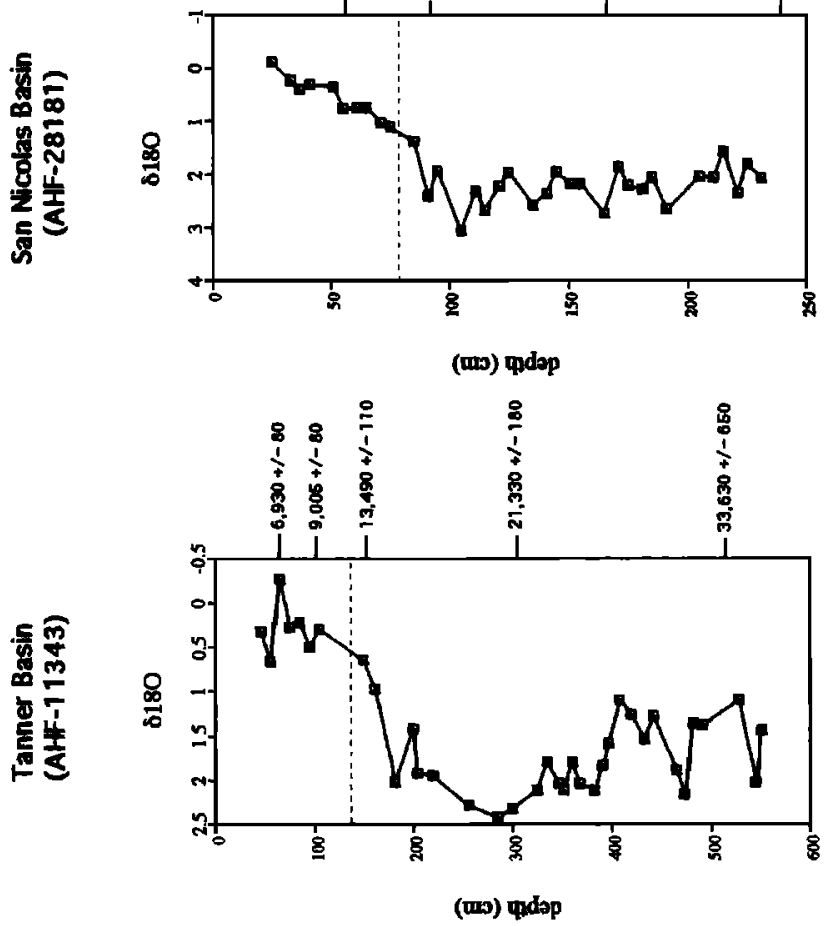

过 


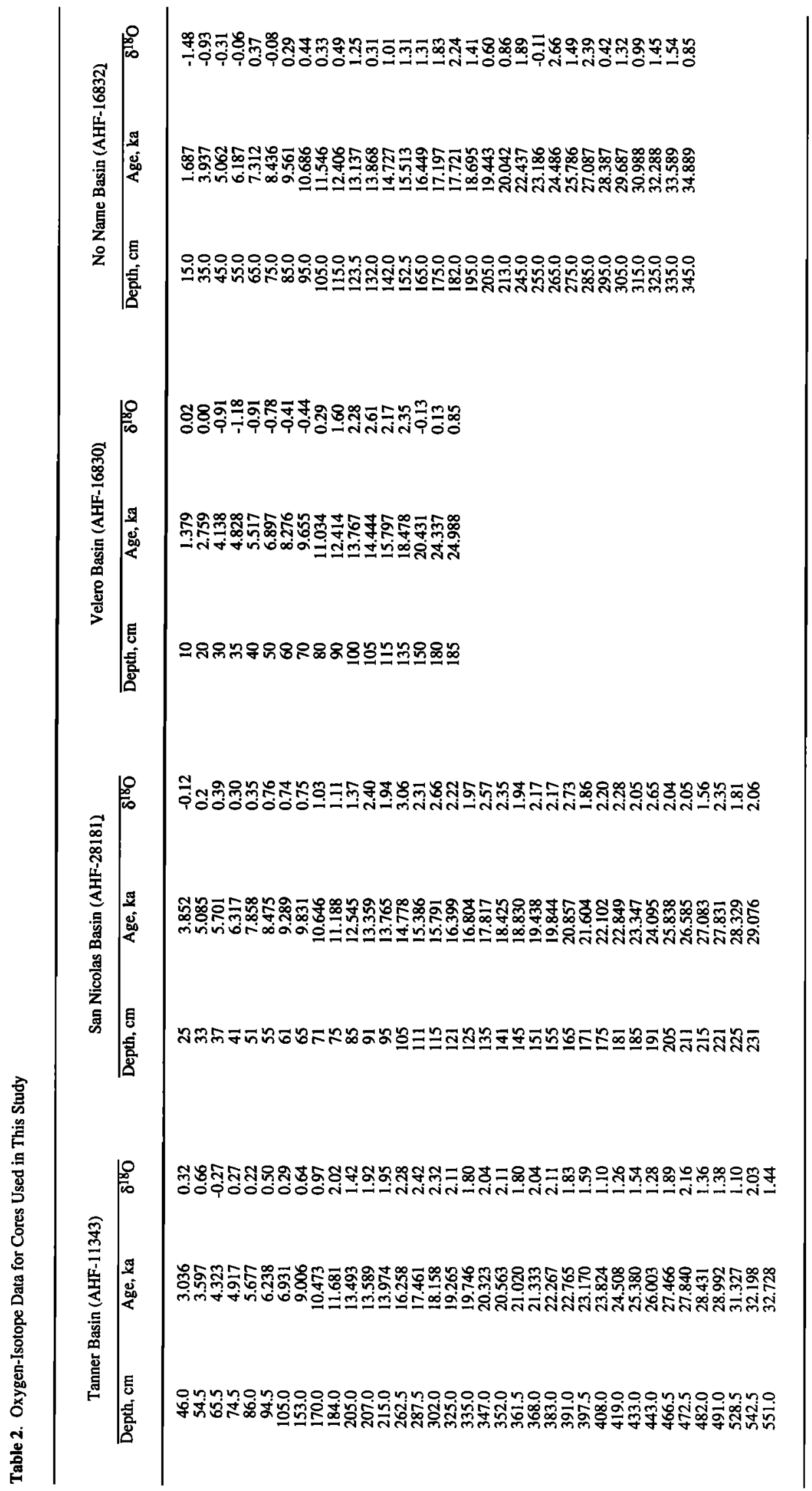


Table 3. Accelerator Mass Spectrometry ${ }^{14} \mathrm{C}$ Ages, Measurement Errors, and Corrected Ages for the Cores Used in This Study

\begin{tabular}{ccccc}
\hline Core & Sample Depth, cm & $1^{14}$ C Age, years & Error, +/- years & $1^{14}$ C Age (Corrected)* \\
\hline AHF-11343 & 105 & 7,330 & 80 & 6,930 \\
AHF-11343 & 153 & 9,405 & 80 & 9,005 \\
AHF-11343 & 205 & 13,890 & 110 & 13,490 \\
AHF-11343 & 368 & 21,730 & 180 & 21,330 \\
AHF-11343 & 565 & 34,030 & 650 & 33,630 \\
AHF-28181 & 54 & 8,870 & 135 & 8,470 \\
AHF-28181 & 90 & 13,755 & 150 & 13,355 \\
AHF-28181 & 164 & 21,250 & 200 & 20,850 \\
AHF-28181 & 234 & 29,965 & 465 & 29,565 \\
AHF-16830 & 90 & 12,810 & 90 & 12,410 \\
AHF-16830 & 130 & 18,220 & 140 & 17,820 \\
AHF-16830 & 200 & 27,340 & 320 & 26,940 \\
AHF-16832 & 95 & 11,090 & 80 & 10,690 \\
AHF-16832 & 142 & 15,130 & 120 & 14,730 \\
AHF-16832 & 255 & 23,590 & 220 & 23,190 \\
AHF-16832 & 355 & 36,600 & 880 & 36,200 \\
& & & & \\
\hline
\end{tabular}

* Correction is 400 years [Bard, 1988].

atmosphere and the sea surface. The apparent age of surface water in the Pacific Ocean at the latitude of the Borderlands is approximately 400 years [Bard, 1988], and this value has been subtracted from our radiocarbon results (Table 3, Figure 3 ).

Using the age model described above, sedimentation rates were calculated for each core by assuming that the top of each core has an age of 0 years and that sedimentation rates are linear between ${ }^{14} \mathrm{C}$ datums. Temporal changes in sedimentation rate for each core are presented in Table 4. Age estimates were linearly interpolated for each core sample, and the $\delta^{18} \mathrm{O}$ records were converted to a timescale (Figure 4). Two of the cores (from Tanner and San Nicolas Basins) had poor recovery of the youngest material, and data are therefore not presented for the uppermost sections.

\section{Micropaleontological Analyses}

A total planktonic foraminiferal faunal analysis was carried out on Tanner Basin core AHF-11343 ( $>150-\mu \mathrm{m}$ size fraction). The key species from this core are discussed as relative abundance data (Table 5; Figure 5). For all four cores, the abundances of sinistral- and dextral-coiling specimens of $N$. pachyderma were determined. All faunal counts were based on approximately 300 specimens per sample. Two types of $N$. pachyderma data were recorded: the number of sinistral-coiling specimens per gram of sediment and the percentage of total $N$. pachyderma specimens that are dextral coiling. These two sets of data were plotted against one another in order to illustrate their inverse trends (Figure 6).

\section{Temperature Estimation}

In the present study, we evaluate average SST changes in the Southern California Borderlands for the last glacial-interglacial cycle using several different approaches. First, planktonic foraminiferal relative abundance patterns for the past 30,000 years are compared with modern seasonal distribution patterns for this region. This comparison allows us to document the response of plankton to changing climate-oceanographic conditions from the LGM to the Holocene. Second, we document temporal changes in the relative abundances of both sinistral- and dextralcoiling varieties of $N$. pachyderma. Bandy [1960] was the first to propose that there is temperature control on the coiling direction of this species. In the Borderlands region, Bandy [1960] found that dextral forms have dominated for the last 11,000 years, whereas sinistral populations dominated during the LGM. Sediment trap results from Station Papa $\left(50^{\circ} \mathrm{N}, 145^{\circ} \mathrm{W}\right)$ in the subpolar northeast Pacific [Reynolds and Thunell, 1986] show that the dextral variety of this species dominates when SSTs are $12^{\circ}-14^{\circ} \mathrm{C}$, whereas sinistral varieties are only present when SSTs at Station Papa are $6^{\circ}-8^{\circ} \mathrm{C}$. A similar study in the North Atlantic [Wolfteich, 1994] also found that sinistral $N$. pachyderma were restricted to SSTs of less than $8^{\circ} \mathrm{C}$. Although stable-isotopic evidence suggests that dextral-coiling $N$. pachyderma dwells beneath the surface mixed layer in the Borderlands region [Thunell and Sautter, 1992], we compare the two forms of this species with SST changes in the higher latitudes of the modern ocean since both coiling varieties are only found in these areas. Sediment trap results from the Borderlands are not useful for this distinction since only dextral-coiling $N$. pachyderma are observed in the modern population from this region [Thunell and Sautter, 1992]. Third, single-species planktonic foraminiferal $\delta^{18} \mathrm{O}$ changes are used to estimate maximum average sea surface temperature changes from the LGM to the present, once the ice volume effect is accounted for [Fairbanks and Matthews, 1978; Fairbanks, 1989] and ignoring unknown surface salinity changes which have not been independently estimated. Fourth, planktonic foraminiferal assemblages are used to derive quantitative estimates of average SST using the modern analog technique 
Table 4. Temporal Changes in Sedimentation Rate for Each Core

\begin{tabular}{|c|c|c|c|c|c|c|c|}
\hline \multicolumn{2}{|c|}{ Tanner Basin } & \multicolumn{2}{|c|}{ San Nicolas Basin } & \multicolumn{2}{|c|}{ Velero Basin } & \multicolumn{2}{|c|}{ No Name Basin } \\
\hline Age, ka & S. R., cm/kyr & Age, ka & S. R., cm/kyr & Age, ka & S. R., cm/kyr & Age, ka & S. R., cm/kyr \\
\hline $\begin{array}{l}0.957 \\
2.013 \\
2.442 \\
3.036 \\
3.597 \\
4.323 \\
4.917 \\
5.677 \\
6.238 \\
6.931 \\
9.006 \\
10.473 \\
11.681 \\
13.493 \\
13.589 \\
13.974 \\
14.358 \\
16.258 \\
17.461 \\
18.158 \\
19.265 \\
19.746 \\
20.323 \\
20.563 \\
21.02 \\
21.333 \\
22.267 \\
22.765 \\
23.17 \\
23.824 \\
24.508 \\
25.38 \\
26.003 \\
27.466 \\
27.84 \\
28.431 \\
28.992 \\
31.327 \\
32.198 \\
32.728 \\
33.63\end{array}$ & $\begin{array}{l}15.15 \\
15.15 \\
15.15 \\
15.15 \\
15.15 \\
15.15 \\
15.15 \\
15.15 \\
15.15 \\
15.15 \\
11.59 \\
11.59 \\
11.59 \\
11.59 \\
20.79 \\
20.79 \\
20.79 \\
20.79 \\
20.79 \\
20.79 \\
20.79 \\
20.79 \\
20.79 \\
20.79 \\
20.79 \\
20.79 \\
16.06 \\
16.06 \\
16.06 \\
16.06 \\
16.06 \\
16.06 \\
16.06 \\
16.06 \\
16.06 \\
16.06 \\
16.06 \\
16.06 \\
16.06 \\
16.06 \\
16.06\end{array}$ & $\begin{array}{r}2.619 \\
3.852 \\
5.085 \\
5.701 \\
6.317 \\
7.858 \\
8.475 \\
9.289 \\
9.831 \\
10.646 \\
11.188 \\
12.002 \\
12.545 \\
13.359 \\
13.765 \\
14.778 \\
15.386 \\
15.791 \\
16.399 \\
16.804 \\
17.412 \\
17.817 \\
18.425 \\
18.83 \\
19.438 \\
19.844 \\
20.451 \\
20.857 \\
21.604 \\
22.102 \\
22.849 \\
23.347 \\
24.095 \\
24.593 \\
25.838 \\
26.585 \\
27.083 \\
27.831 \\
28.329 \\
29.076 \\
29.574 \\
\end{array}$ & $\begin{array}{l}6.49 \\
6.49 \\
6.49 \\
6.49 \\
6.49 \\
6.49 \\
6.49 \\
7.37 \\
7.37 \\
7.37 \\
7.37 \\
7.37 \\
7.37 \\
7.37 \\
9.87 \\
9.87 \\
9.87 \\
9.87 \\
9.87 \\
9.87 \\
9.87 \\
9.87 \\
9.87 \\
9.87 \\
9.87 \\
9.87 \\
9.87 \\
9.87 \\
8.03 \\
8.03 \\
8.03 \\
8.03 \\
8.03 \\
8.03 \\
8.03 \\
8.03 \\
8.03 \\
8.03 \\
8.03 \\
8.03 \\
8.03\end{array}$ & $\begin{array}{r}1.379 \\
2.759 \\
4.138 \\
5.517 \\
6.897 \\
8.276 \\
9.655 \\
11.034 \\
12.414 \\
13.767 \\
15.12 \\
16.473 \\
17.827 \\
19.129 \\
20.431 \\
21.733 \\
23.035 \\
24.337 \\
25.639 \\
26.941\end{array}$ & $\begin{array}{l}7.25 \\
7.25 \\
7.25 \\
7.25 \\
7.25 \\
7.25 \\
7.25 \\
7.25 \\
7.25 \\
7.39 \\
7.39 \\
7.39 \\
7.39 \\
7.68 \\
7.68 \\
7.68 \\
7.68 \\
7.68 \\
7.68 \\
7.68\end{array}$ & $\begin{array}{l}0.225 \\
1.687 \\
2.812 \\
3.937 \\
5.062 \\
6.187 \\
7.312 \\
8.436 \\
9.561 \\
10.686 \\
11.546 \\
12.406 \\
13.137 \\
13.868 \\
14.727 \\
15.513 \\
16.449 \\
17.197 \\
17.721 \\
18.695 \\
19.443 \\
20.042 \\
20.94 \\
21.689 \\
22.437 \\
23.186 \\
24.486 \\
25.786 \\
27.087 \\
28.387 \\
29.687 \\
30.988 \\
32.288 \\
33.589 \\
34.889 \\
36.189\end{array}$ & $\begin{array}{r}8.89 \\
8.89 \\
8.89 \\
8.89 \\
8.89 \\
8.89 \\
8.89 \\
8.89 \\
8.89 \\
8.89 \\
11.63 \\
11.63 \\
11.63 \\
11.63 \\
11.63 \\
13.36 \\
13.36 \\
13.36 \\
13.36 \\
13.36 \\
13.36 \\
13.36 \\
13.36 \\
13.36 \\
13.36 \\
13.36 \\
7.69 \\
7.69 \\
7.69 \\
7.69 \\
7.69 \\
7.69 \\
7.69 \\
7.69 \\
7.69 \\
7.69\end{array}$ \\
\hline
\end{tabular}

S. R., sedimentation rate.

(MAT) [Hutson, 1979; Overpeck et al., 1985; Prell, 1985]. Finally, changes in the spatial occurrence of indicator coccolithophore species relative to their current biogeography are used to infer SST changes since the LGM.

\section{Results}

\section{Tanner Basin Planktonic Foraminiferal Species Census Data}

The planktonic foraminiferal data for the Tanner Basin core (AHF-11343) (Table 5; Figure 5) are compared with recent sediment trap results from three locations in the Pacific (Panama Basin, San Pedro Basin, and Gulf of Alaska [Sautter and Thunell, 1991]), plankton tow results from the northern and equatorial Pacific [Bradshaw, 1959], and surface sediment data from the North Pacific [Coulbourn et al., 1980] in order to interpret temporal changes in species composition as a function of changing climate-oceanographic conditions. Planktonic foraminiferal populations along the eastern margin of the North Pacific undergo distinct changes in species composition in response to seasonal changes in upper ocean conditions [Thunell et al., 1983; Sautter and Thunell, 1989, 1991]. The faunalenvironmental relationships observed in these studies provide a basis for interpreting the glacial-interglacial planktonic foraminiferal changes observed in the Borderlands.

Four taxa (Globigerina bulloides, Globigerina quinqueloba, dextral $N$. pachyderma, and sinistral $N$. pachyderma) dominate the planktonic foraminiferal fauna in the Borderlands region during the last glacial-interglacial cycle (Table 5; Figure 5). Collectively, these species typically account for over $80 \%$ of the total fauna during this period. Globigerina bulloides is most abundant in high latitudes of the Pacific and in low-latitude upwelling regions [Bradshaw, 1959; Coulbourn et al., 1980]. In 

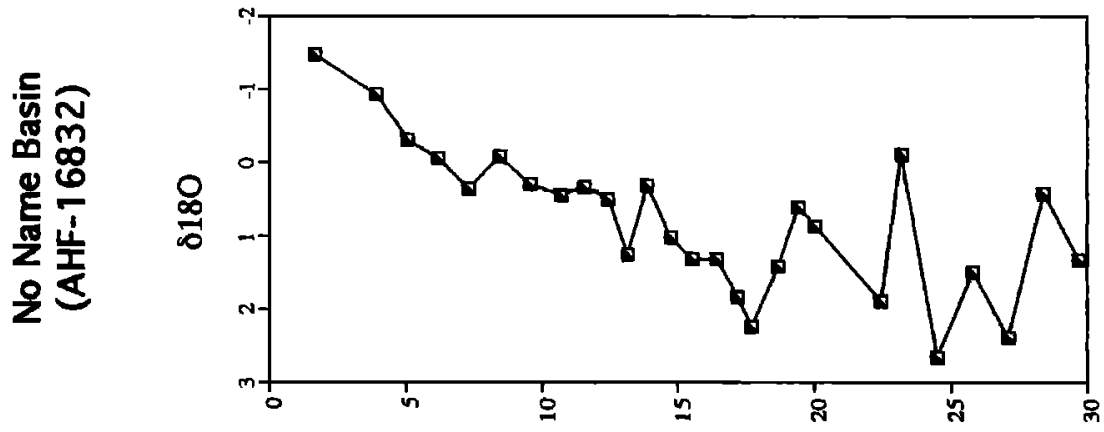

(เบ) วซีะ

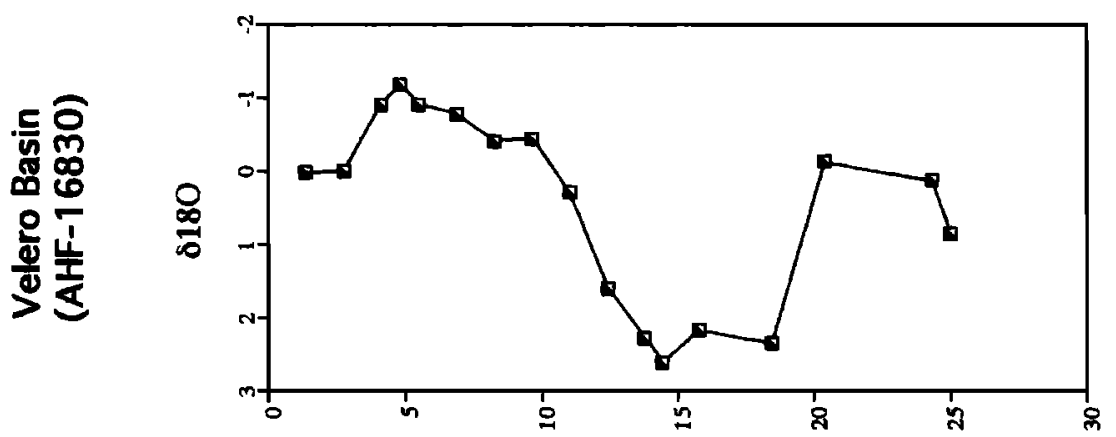

总

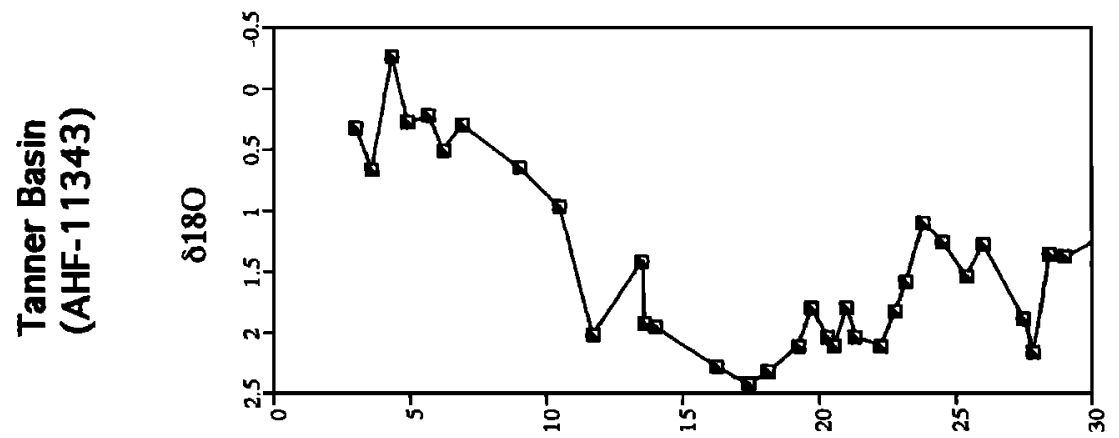

(Е) 


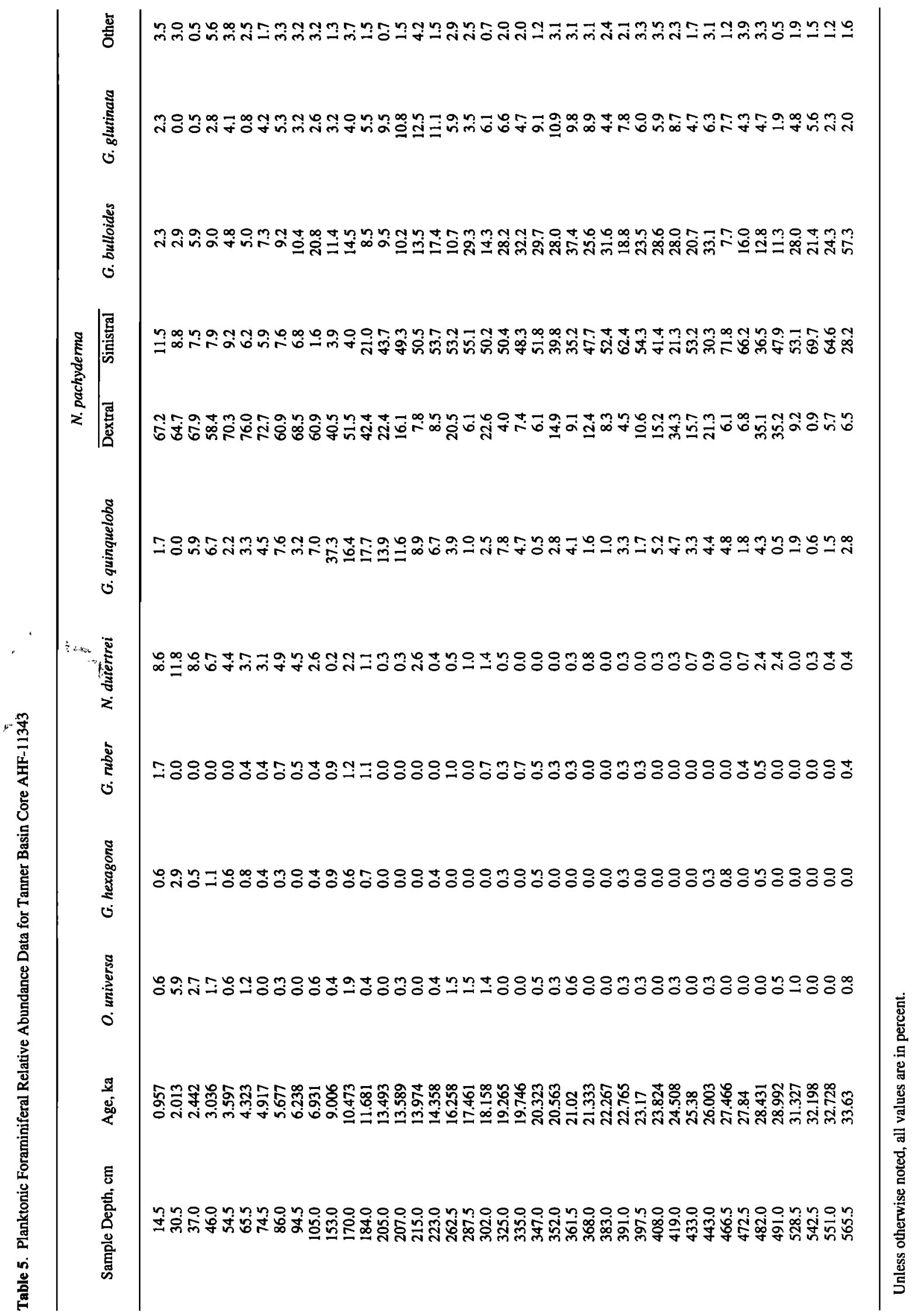




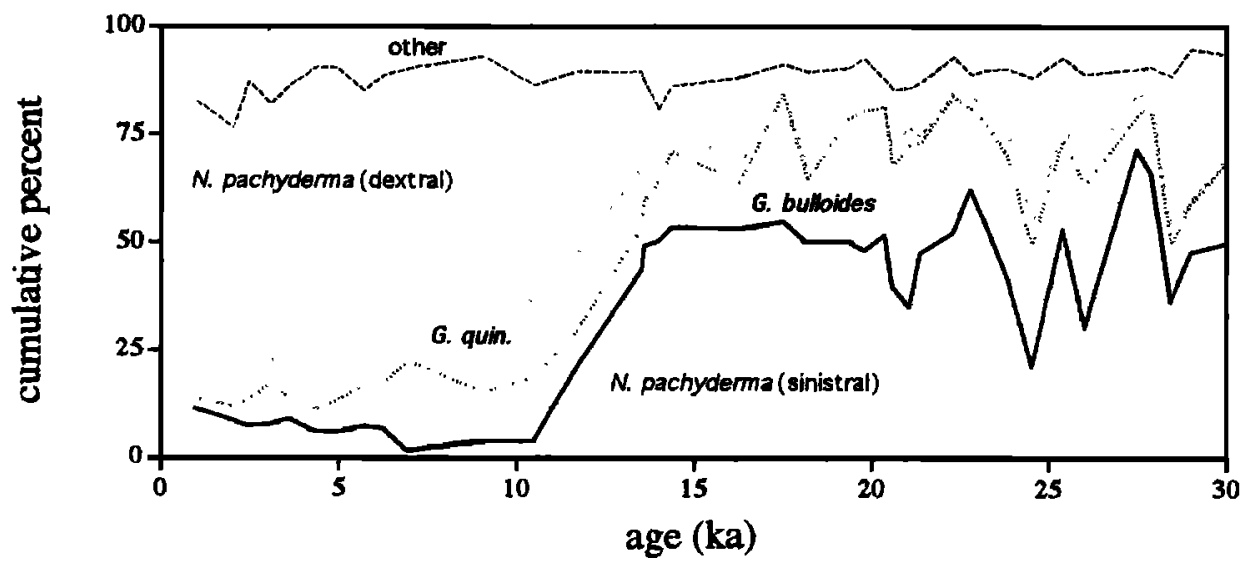

Figure 5. Planktonic foraminiferal relative abundance data for Tanner Basin core AHF-11343 plotted as cumulative percent. Only the four most abundant species are shown. Other refers to all other planktonic foraminiferal species.

both San Pedro and Panama Basins, the shell flux of this species is highest during times of upwelling [Thunell et al., 1983; Sautter and Thunell, 1991]. Similar observations have been made in other upwelling regions [Fischer et al., 1983; Prell, 1984]. Our results for core AHF-11343 show $G$. bulloides to occur in high abundances from about 7-11 ka and also from about $18-28 \mathrm{ka}$, at which times it accounts for over $20 \%$ and $35 \%$ of the total assemblage, respectively (Table 5; Figure 5).

Globigerina quinqueloba is common in the cold waters of the subarctic region of the North Pacific and is also found in the transition regions represented by the California and Peru Currents [Bradshaw, 1959; Coulbourn et al., 1980]. Sediment trap results show this species to prefer upwelling conditions with SSTs of $12^{\circ}-14^{\circ} \mathrm{C}$ in San Pedro Basin [Sautter and Thunell, 1991], and isothermal water-column conditions with SSTs of $5^{\circ}-6^{\circ} \mathrm{C}$ at Station Papa [Reynolds and Thunell, 1986]. The modern plankton regime of the Pacific Ocean suggests that $G$. quinqueloba is a cold-water species that can also occur in upwelling regions. The highest abundance $(-35 \%)$ of this species in Tanner Basin core AHF-1 1343 occurs at 8-10 ka, at the end of the last deglaciation (Table 5; Figure 5).

\section{Abundance and Coiling Direction Changes of Neogloboquadrina Pachyderma}

All four cores show a peak in the number of sinistral-coiling $N$. pachyderma at approximately $15 \mathrm{ka}$ (Figure 6). This is followed by a sharp increase in the percentage of dextral-coiling $N$. pachyderma at the oxygen-isotope stage 1-2 boundary (termination I). This change in coiling direction provides a reliable indicator of the last glacial termination and was previously noted by Gorsline and Prensky [1975].

The abrupt glacial-interglacial changes observed in sinistraland dextral-coiling varieties of $N$. pachyderma can be compared with the seasonal changes observed in this species at Station Papa $\left(50^{\circ} \mathrm{N}, 145^{\circ} \mathrm{W}\right)$ in the North Pacific. Reynolds and Thunell [1986] found that these two taxa prefer very distinct SST and thermocline structure conditions. The sinistral-coiling variety prefers SSTs in the range of $6^{\circ}-8^{\circ} \mathrm{C}$, whereas the dextral-coiling variety prefers SSTs in the range of $12^{\circ}-14^{\circ} \mathrm{C}$ at this location. On the basis of sediment trap results from several locations in the North Atlantic, Wolfteich [1994] also found that sinistral $N$. pachyderma preferred temperatures less than $8^{\circ} \mathrm{C}$, whereas the dextral-coiling form was more common at warmer temperatures. These changes in $N$. pachyderma coiling associated with seasonal SST changes may serve as a modern analog for the glacialinterglacial faunal changes observed in our cores.

While the abrupt change in coiling direction at termination I is common to all four cores, there are intercore differences in the abundance of sinistral-coiling $N$. pachyderma. The Tanner and San Nicolas Basin cores contain multiple peaks in sinistral $N$. pachyderma abundance during glacial stage 2 (Figure 6). In contrast, the cores from Velero and No Name Basins are marked by only a single peak in the abundance of this species at the end of stage 2 (Figure 6).

\section{Planktonic Foraminiferal $\delta^{18} O$ Changes}

The planktonic foraminiferal oxygen-isotope records for each core are plotted against age in Figure 4. In each of the four Borderlands cores, a $2.5-3.5 \% 0 \delta^{18} \mathrm{O}$ change is observed from the LGM to the Holocene. Subtracting the $1.3 \%$ ice volume effect [Fairbanks and Matthews, 1978; Fairbanks, 1989] from the total glacial-interglacial $\delta^{18} \mathrm{O}$ change leaves a residual of $1.2-2.2 \%$ that must be attributed to salinity and/or temperature changes at the depths where $G$. bulloides lives. If the residual is due entirely to salinity changes, this would mean a freshening of approximately 3-5\%o (according to a relationship plotted by Berger and Gardner [1975]) during the last deglaciation, which seems unlikely. We suspect that some combination of both salinity and temperature change leads to the observed residual, but the relative importance of each is unknown. If salinity changes are ignored and the entire $1.2-2.2 \% \delta^{18} \mathrm{O}$ residual is attributed to temperature, this would indicate a maximum average temperature difference of $5^{\circ}-10^{\circ} \mathrm{C}$ between the LGM and present (Table 6). This estimation is based on the paleotemperature equation of Epstein et al. [1953], which predicts a $4.5^{\circ} \mathrm{C}$ change for each $1.0 \%$ change in $\delta^{18} \mathrm{O}$.

\section{Other Evidence for Glacial-Interglacial SST Changes}

In order to evaluate glacial-interglacial SST changes in the Borderlands further, we used the modern analog technique (MAT) for paleotemperature estimation [Hutson, 1979; Overpeck et al., 1985; Prell, 1985] and coccolithophore distributions. For the MAT, downcore foraminiferal assemblages are compared 


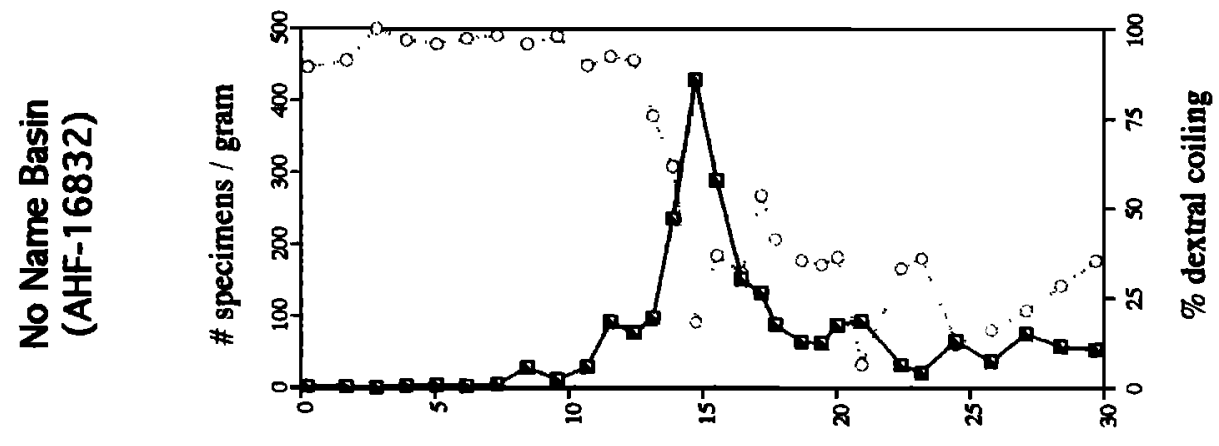

(เx) ว8ื

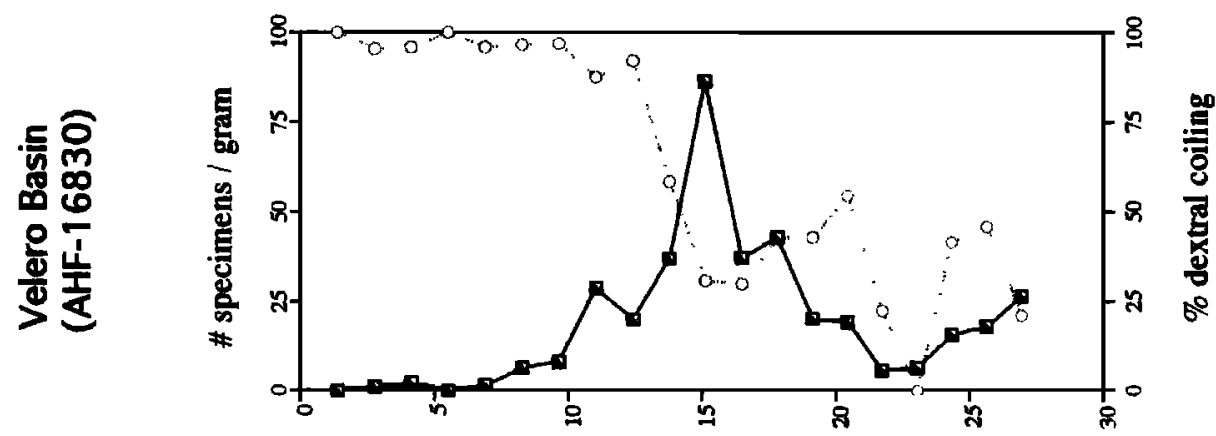

(EX) $ә 8 x$
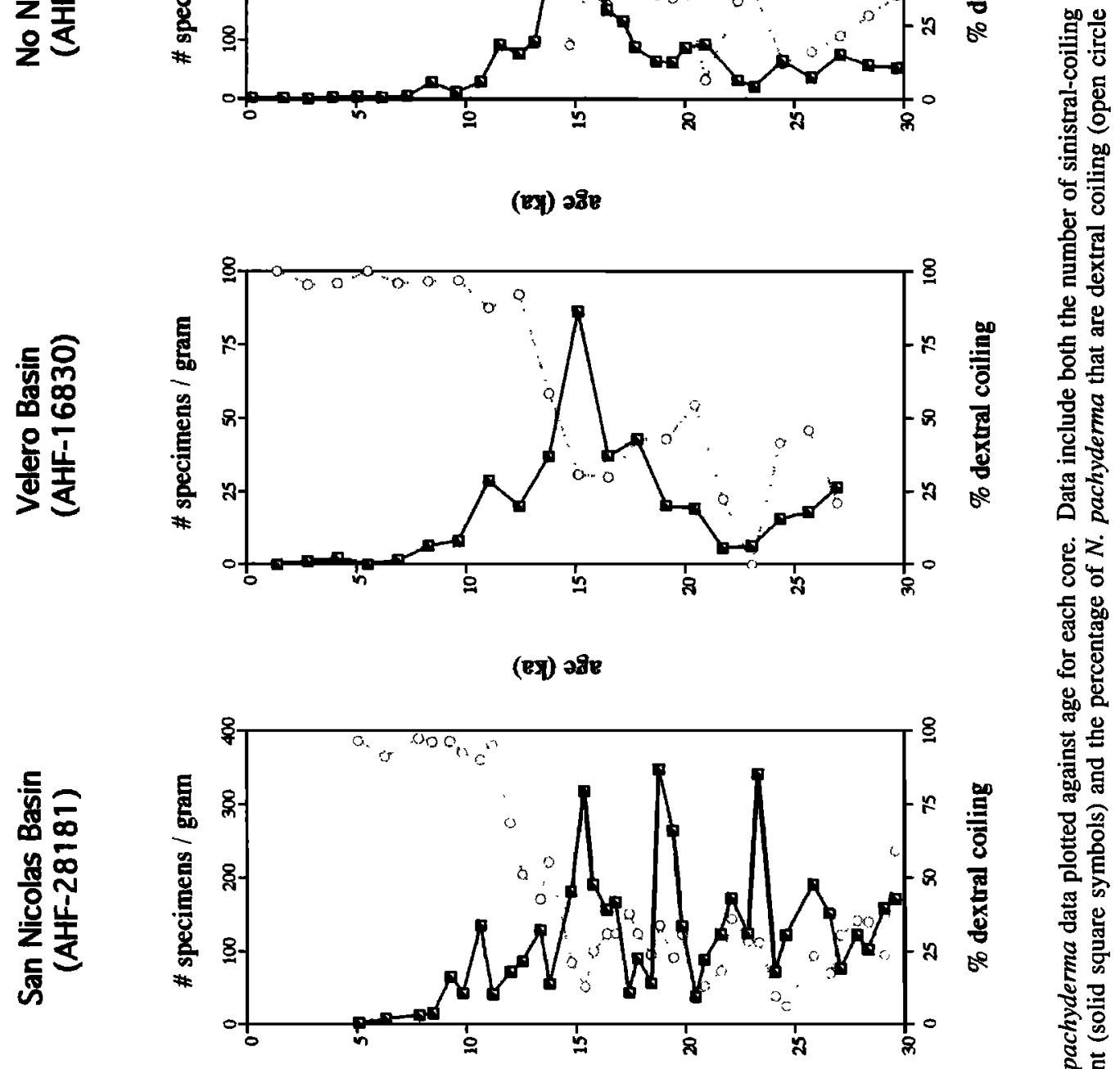

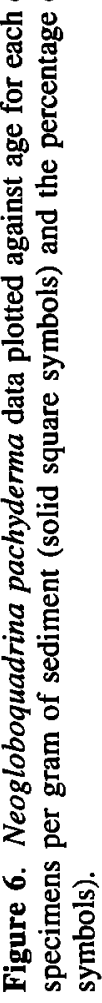

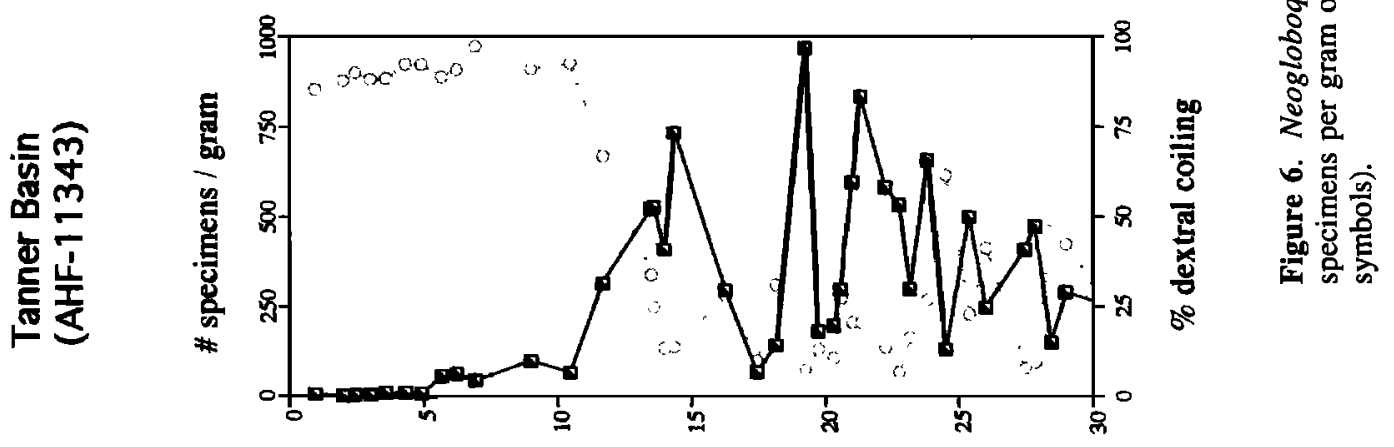

(피) ว8ి8 
Table 6. Glacial-Interglacial Oxygen-Isotope Data for Each Core and Estimated Temperature Changes

\begin{tabular}{lccc}
\hline Core & GlA, ${ }^{\text {a } \% o}$ & Residual, ${ }^{\text {b } \% o}$ & Temperature Effect, ${ }^{\circ} \mathrm{C}$ \\
\hline $\begin{array}{l}\text { Tanner Basin } \\
\text { (AHF-11343) }\end{array}$ & 2.5 & 1.2 & 5.4 \\
$\begin{array}{l}\text { San Nicolas Basin } \\
\text { (AHF-28181) }\end{array}$ & 2.5 & 1.2 & 5.4 \\
$\begin{array}{l}\text { Velero Basin } \\
\text { (AHF-16830) } \\
\text { No Name Basin } \\
\text { (AHF-16832) }\end{array}$ & 3.0 & 1.7 & 7.7 \\
\end{tabular}

${ }^{a}$ GIA, glacial-interglacial $\Delta \delta^{18} \mathrm{O}$ amplitude.

$\mathrm{b}_{\text {Residual }}=$ GIA minus $1.3 \%$.

with a core-top calibration database [Prell, 1985], and the 10 most similar analogs are selected using the squared-chord dissimilarity measurement (a 0.4 cutoff value was used) [Overpeck et al., 1985]. Winter and summer SSTs associated with each of the analogs are averaged to produce SST estimates for the downcore samples. Glacial samples ( $18 \mathrm{ka})$ were selected from each core, and winter and summer average SSTs were estimated using this procedure (Table 7). These glacial SST estimates are compared with present-day temperatures in the region and indicate that the average glacial-interglacial temperature differences for summer and winter were approximately $7^{\circ} \mathrm{C}$ and $9^{\circ} \mathrm{C}$, respectively (Table 7).

In terms of the modern biogeography of coccolithophores, it has been well established that Coccolithus pelagicus is primarily restricted to subpolar regions where water temperatures range between $6^{\circ}$ and $14^{\circ} \mathrm{C}$ [Okada and McIntyre, 1977; McIntyre et al., 1970]. Scanning electron microscope (SEM) studies of samples from the Tanner Basin core reveal distinctly different abundances of this flora for the last glacial and the Holocene. Coccolithus pelagicus is abundant in glacial samples and very rare to absent in Holocene samples. In addition, $C$. pelagicus is not found in sediment trap samples from several locations in the Borderlands (P. Ziveri, personal communication, 1994), suggesting it is not part of the modern flora in this region. The glacial-interglacial difference in the occurrence of this coccolithophore is a further indication that subpolar waters may have extended down the eastern margin of the North Pacific to the Borderlands region during the LGM.

\section{Discussion}

\section{Average Sea Surface Temperature Changes}

The planktonic foraminiferal changes contained in Tanner Basin core AHF-11343 (Table 5, Figures 5 and 6) reflect the changing climate-oceanographic conditions in the Borderlands region during the last glacial-interglacial cycle. The glacial assemblage is dominated by sinistral-coiling $N$. pachyderma and G. bulloides, with minor amounts of the other species. During deglaciation (approximately 14-10 ka), there is a shift in the $N$. pachyderma population from sinistral- to dextral-coiling

Table 7. Summary of Modern Observed Sea Surface Temperatures and Glacial Modern Analog Sea Surface Temperature Estimates

\begin{tabular}{|c|c|c|c|c|c|c|}
\hline \multirow[b]{2}{*}{ Core } & \multicolumn{3}{|c|}{ Winter } & \multicolumn{3}{|c|}{ Summer } \\
\hline & Modem, ${ }^{\circ} \mathrm{C}$ & Glacial, ${ }^{\circ} \mathrm{C}$ & $\Delta$ SST, ${ }^{\circ} \mathrm{C}$ & Modern, ${ }^{\circ} \mathrm{C}$ & Glacial, ${ }^{\circ} \mathrm{C}$ & $\triangle S S T,{ }^{\circ} \mathrm{C}$ \\
\hline \multirow{5}{*}{$\begin{array}{c}\text { Northern Basins } \\
\text { Tanner Basin } \\
\text { (AHF-11343) } \\
\text { San Nicolas Basin } \\
\text { (AHF-28181) } \\
\text { Southern Basins } \\
\text { Velero Basin } \\
\text { (AHF-16830) } \\
\text { No Name Basin } \\
\text { (AHF-16832) }\end{array}$} & & & & & & \\
\hline & 14.0 & 4.4 & 9.6 & 15.2 & 9.1 & 6.1 \\
\hline & 14.1 & 5.6 & 8.5 & 16.7 & 10.5 & 6.2 \\
\hline & 14.9 & 5.2 & 9.7 & 17.2 & 9.9 & 7.3 \\
\hline & 14.8 & 5.3 & 9.6 & 17.2 & 10.1 & 7.1 \\
\hline Mean SSTs & 14.5 & 5.1 & 9.4 & 16.6 & 9.9 & 6.7 \\
\hline
\end{tabular}

SST, sea surface temperature. 
individuals and an increase in the abundance of $G$. quinqueloba. The Holocene assemblage is dominated by dextral-coiling $N$. pachyderma, with minor occurrences of $G$. quinqueloba and $G$. bulloides. The decrease in abundance of $G$. bulloides during deglaciation may be an indicator of reduced upwelling throughout this period. Similarly, the decrease in G. quinqueloba throughout most of the Holocene may indicate warmer SSTs and less upwelling after approximately $7 \mathrm{ka}$.

During deglaciation, the number of sinistral-coiling $N$. pachyderma specimens per gram of sediment decreases by at least a factor of 3 in each core, coincident with an increase in the percentage of dextral-coiling specimens (Figure 6). This is clearly a biotic response to the rapid changes in climateoceanographic conditions in this region at the termination of the last glaciation. Several workers [Kheradpir, 1968, 1970; Gorsline and Prensky, 1975] have used the coiling ratio of $N$. pachyderma in the Borderlands to study the last glacialinterglacial transition. Gorsline and Prensky [1975] suggested that the change in coiling direction represents the passage through this region of average annual surface water temperatures of $8^{\circ}$ $10^{\circ} \mathrm{C}$. Our observation of an abrupt coiling change during deglaciation agrees well with these findings.

Gorsline and Barnes [1972] had previously concluded from $\delta^{18} \mathrm{O}$ data that average glacial SSTs were approximately $8^{\circ} \mathrm{C}$ in the Borderlands and warmed to approximately $14^{\circ} \mathrm{C}$ during the Holocene. Similarly, Kahn et al. [1981] used planktonic foraminiferal $\delta^{18} \mathrm{O}$ changes to estimate that average glacial temperatures in this region were approximately $5^{\circ} \mathrm{C}$ colder than present. After accounting for the $1.3 \%$ ice volume effect [Fairbanks and Matthews, 1978; Fairbanks, 1989], our oxygenisotope results suggest an average maximum cooling of $5^{\circ}-10^{\circ} \mathrm{C}$ during the LGM, in close agreement with the earlier isotopic results.

The MAT-derived SST estimates based on planktonic foraminifera also suggest that average glacial SSTs were approximately $7^{\circ}-9^{\circ} \mathrm{C}$ lower than at present in the Borderlands region (Table 7). In addition, the occurrence of the subarctic coccolith $C$. pelagicus in the Borderlands during the LGM suggests that SSTs in this region were significantly cooler during the LGM. In summary, a combination of faunal, floral, and stable-isotopic evidence indicates that a substantial cooling $\left(6^{\circ}\right.$ $10^{\circ} \mathrm{C}$ ) of average SST occurred since the LGM in the Southern California Borderlands. This observation is supported by recent findings from Santa Barbara Basin, where planktonic foraminiferal assemblage changes suggest a $7^{\circ}-8^{\circ} \mathrm{C}$ warming throughout the last deglaciation [Kennett and Venz, 1995], and planktonic foraminiferal $\delta^{18} \mathrm{O}$ contrasts [Kennett and Ingram, 1995] are similar to those observed in the Borderlands. Our findings are further supported by the work of Prahl et al. [1995], in which they used the $\mathbf{U}^{\mathbf{k}}{ }_{37}$ technique to demonstrate that SSTs at $42^{\circ} \mathrm{N}$ in the California Current were approximately $6^{\circ} \mathrm{C}$ during the last glacial and warmed to $12^{\circ} \mathrm{C}$ during the Holocene.

The dominance of sinistral-coiling $N$. pachyderma and the presence of the coccolith $C$. pelagicus in our cores during the LGM suggests that subpolar surface waters extended southward along the eastern margin of the North Pacific to at least the Borderlands region at this time. It has been suggested that the Laurentide ice sheet caused the North Pacific high-pressure cell to move farther south and closer to the continent during the LGM relative to its present position [COHMAP, 1988]. Because the position and strength of this atmospheric high controls the flow of the California Current [Hickey, 1979; Huyer, 1983], the proposed reorientation of the atmospheric pressure cells may have strengthened this eastern boundary current. Increased equatorward transport of subarctic waters by the California Current best explains not only the estimated cooling of surface waters but also the marked increase in the occurrence of subarctic fauna and flora in the Borderlands during the LGM. In order to explain these changes observed in the Borderlands, we suggest that an expansion of the subpolar zone toward the equator and a strengthening of the California Current occurred during the last glacial.

Climate: Long-Range Investigation, Mapping, and Prediction (CLIMAP) [1976, 1981] used a series of microfossil-based transfer functions to predict global changes in SST during the last glacial maximum. Their estimated glacial winter SSTs for the Borderlands region are $12^{\circ}-13^{\circ} \mathrm{C}$ [CLIMAP, 1981], or only about $2^{\circ} \mathrm{C}$ cooler than present-day winter temperatures. The large discrepancy between our results and those of CLIMAP [1981] may be due to one or more of several possibilities. First, their core coverage for this region of the northeast Pacific may not have been adequate, resulting in extrapolation of SSTs over broad areas. In addition, the temperature calibration data set used by CLIMAP [1981] is from an old compilation of modern values which smoothes out the high temperature gradient areas in eastern boundary currents, thus removing some accuracy of modern temperature values for comparison to the last glacial. Finally, the temperature estimations used in the CLIMAP [1981] reconstruction for this region are based only on radiolarians; thus there may be an ecological difference in the response of radiolarians and foraminifera in boundary current or upwelling regimes not accounted for in the equations used ( $T$. Moore, personal communication, 1995).

\section{Climatic Instability During the Last Glacial}

The four cores used in this study are marked by two different patterns in the abundance of sinistral $N$. pachyderma (Figure 6). All four cores show a peak in sinistral-coiling $N$. pachyderma/gram at approximately $15 \mathrm{ka}$ (end of the last glacial). For the cores from the two southern basins (Velero and No Name), the early part of glacial stage 2 is not marked by any intervals of high abundance of this taxa. In contrast, the cores from the two northern basins (Tanner and San Nicolas) contain three peaks in sinistral-coiling $N$. pachyderma abundance during glacial stage 2 (Figure 6). If high abundances of this species reflect the presence of subpolar waters, then the observed differences between the basins may provide information on the frequency and spatial extent of these subpolar incursions. We propose that the northern part of the Borderlands experienced repeated advances and retreats of subpolar waters during the last glacial. In contrast, subpolar waters only extended to the southern sector of the Borderlands at the end of the last glacial.

The high-frequency changes in abundance of sinistral-coiling $N$. pachyderma during the last glacial in the northern Borderlands region may have more than just regional significance. Recent studies of Greenland ice cores [Dansgaard et al., 1993; Grootes et al., 1993; Taylor et al., 1993] and North Atlantic sediment cores [Bond et al., 1992, 1993] indicate that the last glacial period was marked by a series of rapid climate changes. Specifically, ice core records [Dansgaard et al., 1993] contain three interstadial events (Dansgaard-Oeschger events) between 15 and $25 \mathrm{ka}$, whereas marine records from the North Atlantic contain 
sedimentological evidence (Heinrich layers) for three coeval periods of massive iceberg production during this time [Bond et al., 1993]. The rapid advances and retreats of subpolar waters into the Borderlands may be another example of the general instability of climate conditions during the last glacial, as well as an indication that this instability is not peculiar to the North Atlantic region [Clark and Bartlein, 1995; Thunell and Mortyn, 1995].

Micropaleontological and stable-isotopic data from four piston cores in the Southern California Borderlands region have been used to estimate average SST changes during the last glacialinterglacial cycle. On the basis of our observations, the following conclusions can be drawn.

1. Changes in the relative abundances of planktonic foraminifera indicate that major climate-oceanographic changes occurred in the Borderlands region during the last 25,000 years. Specifically, an abrupt change in the coiling direction of $N$. pachyderma occurred during deglaciation, with sinistral-coiling forms being replaced by dextral-coiling individuals at 13-14 ka. The presence of sinistral-coiling $N$. pachyderma in this region during the last glacial is interpreted as indicating that subpolar surface waters extended into the Borderlands region during that time.

2. A planktonic foraminiferal $\delta^{18} \mathrm{O}$ change of $1.2-2.2 \%$ in excess of the ice volume effect in each of our cores suggests that average glacial SSTs may have been as much as $5^{\circ}-10^{\circ} \mathrm{C}$ cooler than present, ignoring any changes in salinity.

3. MAT-derived SST estimates for the LGM are $7^{\circ}-9^{\circ} \mathrm{C}$ cooler than at present and are thus consistent with the stable-isotope results. In addition, a subarctic coccolith, $C$. pelagicus, is abundant in glacial Borderlands samples. This suggests that a southward advancement of the subpolar waters along the eastern margin of the North Pacific may have occurred during the last glacial, bringing with it considerably cooler average SSTs.

4. Our results collectively suggest a $6^{\circ}-10^{\circ} \mathrm{C}$ cooling of average SSTs in the Borderlands during the last glacial. This is considerably larger than that predicted by CLIMAP [1981], probably due to their lack of core coverage in the eastern North Pacific, an inaccurate modern database for their temperature calibration, and use of radiolarians (versus foraminifera) in their transfer function equations.

5. Repeated advances and retreats of subpolar surface waters occurred in the Borderlands region during the last glacial. On the basis of abundance patterns of sinistral-coiling $N$. pachyderma in our cores, the northern basins contain evidence for multiple advances/retreats of the subpolar waters during the last glacial, whereas the southern basins record only a single incursion of subpolar waters. These observations are a further indication of the general instability of climate conditions during the last glacial period.

Acknowledgments. This work was undertaken as part of an M.S. thesis by P.G.M. at the University of South Carolina. We thank D. Gorsline tor providing samples, E. Tappa and L. Ember for performing stable isotope analyses, and $P$. Ziveri for conducting the scanning electron microscope (SEM) work on the calcareous nannofossils. The helpful reviews of J. Kennett, T. Moore, J. Gardner, M. Delaney, and K. Miller are gratefully acknowledged. This work was supported by NSF grants OCE9102151 and OSR-9108772 to R.C.T.

\section{References}

Bandy, O.L., Geological significance of coiling ratios in the foraminifer Globigerina pachyderma (Ehrenberg), $J$. Paleontol., 4, 671-681, 1960.

Bard, E., Correction of accelerator mass spectrometry ${ }^{14} \mathrm{C}$ ages measured in planktonic foraminifera: Paleoceanographic implications, Paleoceanography, 3, 635-645, 1988.

Berelson, W.M., D.E. Hammond, and K.S. Johnson, Benthic fluxes and the cycling of biogenic silica and carbon in two southern California borderland basins, Geochim. Cosmochim. Acta, 51, 1345-1364, 1987.

Berger, W.H., and J.V. Gardner, On the determination of Pleistocene temperatures from planktonic foraminifera, $J$. Foraminiferal Res., 5, 102-113, 1975.

Bond, G., et al., Evidence for massive discharges of icebergs into the North Atlantic Ocean during the last glacial period, Nature, $360,245-249,1992$.

Bond, G., W. Broecker, S. Johnsen, J. McManus, L. Labeyrie, J. Jouzel, and G. Bonani, Correlations between climate records from North Atlantic sediments and Greenland ice, Nature, 365 , 143-147, 1993.

Bradshaw, J.S., Ecology of living planktonic foraminifera in the north and equatorial Pacific Ocean, Contrib. Cushman Found. Foraminiferal Res., 10, 25-64, 1959.

Clark, P., and P. Bartlein, Correlation of late Pleistocene glaciation in the western United States with North Atlantic Heinrich events, Geology, 23, 483-486, 1995.

Climate: Long-Range Investigation, Mapping, and Prediction (CLIMAP) Project Members, The surface of the ice-age Earth, Science, 191, 1131-1137, 1976.

CLIMAP Project Members, Seasonal reconstruction of the Earth's surface at the last glacial maximum, Geol. Soc. Am. Map Chart Ser., $M C-36,1981$.

Cooperative Holocene Mapping Project (COHMAP) Members, Climatic changes of the last 18,000 years: Observations and model simulations, Science, 24I, 1043-1052, 1988.

Coulbourn, W.T., F.L. Parker, and W.H. Berger, Faunal and solution patterns of planktonic foraminifera in surface sediments of the North Pacific, Mar. Micropaleontol., 5, 329 $399,1980$.

Dansgaard, W., et al., Evidence for general instability of past climate from a 250-kyr ice-core record, Nature, 364, 218-220, 1993.

Eppley, R.W. (Ed.), Plankton Dynamics of the Southern California Bight, vol. 15, 373 pp., Springer-Verlag, New York, 1986.

Epstein, S., R. Buchsbaum, H.A. Lowenstam, and H.C. Urey, Revised carbonate-water isotopic temperature scale, Geol. Soc. Am. Bull., 64, 1315-1325, 1953.

Fairbanks, R.G., A 17,000-year glacio-eustatic sea level record: Influence of glacial melting rates on the Younger Dryas event and deep-ocean circulation, Nature, 342, 637-642, 1989.

Fairbanks, R.G., and R.K. Matthews, The marine oxygen isotope record in Pleistocene coral, Barbados, West Indies, Quat. Res., 10, 181-196, 1978.

Fischer, K., J. Dymond, C. Moser, D. Murray, and A. Mathern, Seasonal variation in particulate flux in an offshore area adjacent to coastal upwelling, in Coastal Upwelling: Its Sedimentary Record, Part A, edited by E. Suess and J. Thiede, pp. 209-224, Plenum, New York, 1983.

Gorsline, D.S., and P.W. Bames, Carbonate variations as climatic indicators in contemporary California flysch basins, Int. Geol. Congr. Rep. Sess. 24th, 6, 270-277, 1972.

Gorsline, D.S., and S.E. Prensky, Paleoclimatic inferences for late Pleistocene and Holocene from California continental borderland basin sediments, in Quaternary Studies-The Royal Society of New Zealand, Wellington, edited by R.P. Suggate and M.M. Cresswell, pp. 147-154, 1975.

Grootes, P.M., M. Stuiver, J.W.C. White, S. Johnsen, and J. Jouzel, Comparison of oxygen isotope records from the GISP2 and GRIP Greenland ice cores, Nature, 366, 552-554, 1993. 
Hickey, B.M., The California Current system: Hypotheses and facts, Prog. Oceanogr., 8, 191-279, 1979.

Hickey, B.M., Variability in two deep coastal basins (Santa Monica and San Pedro) off southern California, Jour. Geophys. Res., 96, 16,689-16,708, 1991.

Hickey, B.M., Circulation over the Santa Monica-San Pedro Basin and shelf, Prog. Oceanog., 30, 37-115, 1992.

Hutson, W.H., The Agulhas Current during the late Pleistocene: Analysis of modern faunal analogs, Science, 207, 64-66, 1979.

Huyer, A., Coastal upwelling in the California Current system, Prog. Oceanogr., 12, 259-284, 1983.

Imbrie, J., and N.G. Kipp, A new micropaleontological method for quantitative paleoclimatology: Application to a late Pleistocene Caribbean core, in Late Cenozoic Glacial Ages, edited by K.K. Turekian, pp. 71-182, Yale University Press, New Haven, 1971.

Imbrie, J., J.D. Hays, D.G. Martinson, A. McIntyre, A.C. Mix, J.J. Morley, N.G. Pisias, W.L. Prell, and N.J. Shackleton, The orbital theory of Pleistocene climate: Support from a revised chronology of the marine $\delta^{18} \mathrm{O}$ record, in Milankovitch and Climate, part I, edited by A.L. Berger et al., pp. 269-305, D. Reidel, Hingham, MA, U.S.A., 1984.

Jahnke, R.A., D. Heggie, S. Emerson, and V. Grundmanis, Pore waters of the central Pacific Ocean: Nutrient results, Earth Planet. Sci. Lett., 61, 233-256, 1982.

Kahn, M.I., T. Oba, and T. Ku, Paleotemperatures and the glacially induced changes in the oxygen-isotope composition of sea water during late Pleistocene and Holocene time in Tanner Basin, California, Geology, 9, 485-490, 1981.

Kennett, J.P., and B.L. Ingram, Paleoclimatic evolution of Santa Barbara Basin during the last 20 k.y.: Marine evidence from Hole 893A, Proc. Ocean Drill. Program Sci. Results, 146, 309-325, 1995.

Kennett, J.P., and K. Venz, Late Quaternary climatically related planktonic foraminiferal assemblage changes: Hole 893A, Santa Barbara Basin, California, Proc. Ocean Drill. Program Sci. Results, 146, 281-293, 1995.

Kheradpir, A., Foraminiferal trends and paleoecology in late Pleistocene-Recent cores, Tanner Basin, California, M.S. thesis, 64 pp., Dep. of Geol. Sci., Univ. of Southern Calif., Los Angeles, 1968.

Kheradpir, A., Foraminiferal trends in the Quaternary of Tanner Basin, California, Micropaleontology, 16, 102-116, 1970.

Martin, W.R., and F.L. Sayles, Seafloor diagenetic fluxes, in Global Surficial Geofluxes, edited by Geophysics Study Committee, Nat. Acad. of Sci., Washington, D. C., 1992.

Martin, W.R., M. Bender, M. Leinen, and J. Orchardo, Benthic organic carbon degradation and biogenic silica dissolution in the central equatorial Pacific, Deep Sea Res., 38, 1481-1516, 1991.

Martinson, D.G., N.G. Pisias, J.D. Hays, J. Imbrie, T.C. Moore Jr., and N.J. Shackleton, Age dating and the orbital theory of the ice ages: Development of a high-resolution 0 to 300,000 year chronostratigraphy, Quat. Res., 27, 1-29, 1987.

McIntyre, A., A.W.H. Be, and M.B. Roche, Modern Pacific coccolithophorida: A paleontological thermometer, Trans. N.Y. Acad. Sci., Ser. II, 32, 720-731, 1970.

Okada, H., and A. McIntyre, Modern coccolithophores of the Pacific and North Atlantic Oceans, Micropaleontology, 23, 1$55,1977$.

Overpeck, J.T., T. Webb III, and I.C. Prentice, Quantitative interpretation of fossil pollen spectra: Dissimilarity coefficients and the method of modern analogs, Quat. Res., 23, 87-108, 1985.

Prahl, F., N. Pisias, M. Sparrow, and A. Sabin, Assessment of sea-surface temperature at $42^{\circ} \mathrm{N}$ in the California Current over the last 30,000 years, Paleoceanography, 10, 763-773, 1995.

Prell, W.L., Variation of monsoonal upwelling: A response to changing solar radiation, in Climate Processes and Climate
Sensitivity, Geophys. Monogr. Ser., vol. 29, edited by J.E. Hansen and T. Takahashi, pp. 48-57, AGU, Washington, D. C., 1984.

Prell, W.L., The stability of low-latitude sea-surface temperatures: An evaluation of the CLIMAP reconstruction with emphasis on the positive SST anomalies, Cont. Rep. DEAC02-83ER60167, U.S. Dep. of Energy, Washington, D. C., 1985.

Reid, J.L., Jr., G.I. Roden, and J.G. Wyllie, Studies of the California Current system, in California Cooperative Oceanic Fisheries Investigations Progress Report, 7-1-56 to 1-1-58, pp. 27-56, Mar. Res. Comm., Calif. Dep. of Fish and Game, Sacramento, 1958.

Reynolds, L.A., and R.C. Thunell, Seasonal production and morphologic variation of Neogloboquadrina pachyderma (Ehrenberg) in the northeast Pacific, Micropaleontology, 32, 1$18,1986$.

Sautter, L.R., and R.C. Thunell, Seasonal succession of planktonic foraminifera: Results from a four-year time-series sediment trap experiment in the northeast Pacific, $J$. Foraminiferal Res., 19, 253-267, 1989.

Sautter, L.R., and R.C. Thunell, Planktonic foraminiferal response to upwelling and seasonal hydrographic conditions: Sediment trap results from San Pedro Basin, Southern California Bight, J. Foraminiferal Res., 21, 347-363, 1991.

Taylor, K.C., G.W. Lamorey, G.A. Doyle, R.B. Alley, P.M. Grootes, P.A. Mayewski, J.W.C. White, and L.K. Barlow, The "flickering switch" of late Pleistocene climate change, Nature, 361, 432-436, 1993.

Thunell, R.C., and P.G. Mortyn, Glacial climate instability in the northeast Pacific Ocean, Nature, 376, 504-506, 1995.

Thunell, R.C., and L.R. Sautter, Planktonic foraminiferal faunal and stable isotopic indices of upwelling: A sediment trap study in the San Pedro Basin, Southern California Bight, in Upwelling Systems: Evolution Since the Early Miocene, Geol. Soc. Spec. Publ. 64, 77-91, 1992.

Thunell, R.C., W.B. Curry, and S. Honjo, Seasonal variation in the flux of planktonic foraminifera: Time series sediment trap results from the Panama Basin, Earth Planet. Sci. Lett., 64, 44 $55,1983$.

Tont, S.A., Short period climatic fluctuations: Effects on diatom biomass, Science, 194, 942-944, 1976.

U.S. GLOBEC, Eastern Boundary Current Program, Report on climate change and the California Current ecosystem, U.S. Global Ocean Ecosystems Dyn. Rep. 7, Davis, CA, September 1992.

Wolfteich, C.M., Satellite-derived sea surface temperature, mesoscale variability, and foraminiferal production in the North Atlantic, M.S. thesis, MIT/WHOI Joint Program in Oceanogr., Mass. Inst. of Technol./Woods Hole Oceanogr. Inst., Woods Hole, Mass., 1994.

D. M. Anderson, NOAA Paleoclimatology Program, 325 Broadway, Boulder, CO 80303. (e-mail: dma@ngdc.noaa.gov)

J. Le and R. C. Thunell, Department of Geological Sciences, University of South Carolina, Columbia, SC 29208. (e-mail: jle@paleo.geol.scarolina.edu; thunell@paleo.geol.scarolina.edu)

P. G. Mortyn, Scripps Institution of Oceanography, 9500 Gilman Dr., La Jolla, CA 92093-0208. (e-mail: mortyn@ucsd.edu)

L. D. Stott, Department of Earth Sciences, University of Southern California, Los Angeles, CA 90089-0740. (e-mail: stott@usc.edu)

(Received May 2, 1995; revised April 12, 1996; accepted May 15, 1996.) 